\title{
A Century of Progress with Vegetative Plant Propagation
}

\author{
John E. Preece \\ Department of Plant, Soil and General Agriculture, Southern Illinois University, MC 4415, Carbondale, IL 62901
}

Some of the most important advances in the history of cloning plants were made during the last 100 years. These have made commercial plant propagation more efficient. This paper is focused on when and how these discoveries were made and when they were adopted by the plant propagation industry. For example, within five years of the discovery of auxin there were three commercial products being manufactured for rooting of cuttings, including Hormodin and Rootone.

I took two primary approaches in researching this paper. Original research articles were searched and plant propagation books and United States Department of Agriculture (USDA) and agricultural experiment station bulletins throughout the past century were perused. The articles provide information about when discoveries were made and the books and bulletins are used as benchmarks to determine when new practices were adopted by the horticultural industry. It is difficult to determine specifically when some of the new methods, such as the use of steam to disinfest propagation media, had become widely adopted by the propagation industry. Some papers, bulletins and books specifically discuss commercial adoption of these new techniques. In other cases, the time when these practices initially appeared in reference/text books and bulletins can be interpreted as an indication of when they were adopted by commercial propagators.

There have been two recent papers on the history of plant propagation (Geneve, 2001; Mendel, 1992). Much of the paper by Geneve (2001) focuses on the ancient history of plant propagation rather than advances during the last century. There is some overlap between this present paper and the manuscript by Mendel (1992). This present paper covers a longer history than the seventy years (about 1920-1990) discussed by Mendel.

\section{VEGETATIVE PROPAGATION IN 1903}

It is instructive to consider the state of the art and science of clonal propagation of plants when the American Society for Horticultural Science (ASHS) formed in 1903. The cutting types that we use today - hardwood, softwood, semihardwood, herbaceous, leaf, and root cuttings, were used at that time (Bailey, 1891, 1896; Corbett, 1902). Propagators were aware that older wood at the base of hardwood cuttings could stimulate rooting of some species and used heel and mallet cuttings when appropriate. Single node cuttings (then called single-eye cuttings but now often called leafbud cuttings) were used to maximize the number of cuttings per stock plant. Rooting was known to be often associated with nodes (called joints in textbooks and USDA publications) and making the bottom cut just below a node was a common recommendation.

The relative ease of rooting cuttings from juvenile plants as compared to adult plants was known by 1900 (Goebel, 1900), but was not yet common knowledge in 1903 and was not mentioned in plant propagation books at that time (Bailey, 1891; 1896; Corbett, 1902). Plant growth substances had not yet been discovered.

A variety of other vegetative propagation techniques that remain in use today were used a century ago as well (Bailey, 1891; 1896; Corbett, 1902). Natural means of vegetative reproduction via rhizomes and stolons were employed by these early propagators. Bulbs and corms were used as propagules. As is the current practice, bulbs were propagated by separation, scooping, scoring, or scaling. Clumping plants were propagated by separation where offsets detach without cutting, or division where cutting is necessary to remove offshoots from the crown of the stock plant. Leaf cuttings were used for various species, such as Begonia rex Putz. King B., succulents, and members of the

I thank librarian Kathy Fahey, Morris Library, Southern Illinois University Carbondale for her help finding some of the more obscure references, as well as those that were cited incompletely in referenced works. She added greatly to the thoroughness of this manuscript. I thank Linda Preece for listening to me think out loud as I developed and improved this manuscript.
Gesneriaceae. Root cuttings were used for various fruit crops, horseradish (Armoracia rusticana P. Gaertn., B Mey. \& Scherb.), and others. It was known that when shoots were regenerated adventitiously, as with root cuttings or leaf cuttings, traits (such as variegation), which are associated with chimeras were lost (Bailey, 1896).

Humidity control was not nearly as good as today's mist and fog systems, but other methods were used and considered very important for leafy cuttings (Bailey, 1891, 1896; Corbett, 1902). Transpiration was minimized by reducing leaf area of cuttings. Nathaniel Ward invented the glass-covered terrarium, known as the Wardian case in 1829 (Hershey, 1996). Therefore, small, high humidity cases had been in use for over 70 years when ASHS formed. Various types of frames and boxes covered with glass sashes and plates were used to maintain a high relative humidity for rooting leafy cuttings 100 years ago. There were problems with cutting rot in these propagation cases, then called damping-off (Bailey, 1891, 1896; Corbett, 1902). Today, damping-off is considered a seed or seedling disease (Agrios, 1997; Hartmann et al., 2002). Because of the stagnant air environment, Botrytis was likely one of the pathogens involved.

Today there is an acute awareness of the importance of strict sanitation to reduce losses associated with diseases in the propagation bed, but sanitation was not a major concern of plant propagators a century ago (Bailey, 1891, 1896; Corbett, 1902). They were aware that damping-off and other important plant propagation diseases were caused by fungi (Bailey, 1891, 1896). Bailey (1896) wrote that "there is no complete remedy" for these propagation diseases. He advocated avoiding both crowding plants and a stagnant, moist environment; as well as reducing watering and using well-drained media. These remain excellent recommendations.

The importance of the use of bottom heat for cuttings was well known and widely used a century ago (Bailey, 1891, 1896; Corbett, 1902). For outdoor propagation, these authors advocated burying hardwood cuttings , such as those of grape (Vitis spp.), upside-down to insulate and protect the buds from low winter temperatures. The butts of the cuttings (proximal ends) were covered with 5 to $7.5 \mathrm{~cm}$ (2 to 3 inches) of sand and the Spring sun would warm them, stimulating rooting. Bottom heat also was provided in greenhouses by flues or heating pipes, by burning a lamp that heated a tray of water under the propagation medium or where the lamp's heat was distributed to the medium by means of a heat funnel, by heating and recirculating hot water, or by fermenting manure (Bailey, 1891, 1896). None of these methods had thermostatic control and the need for a higher temperature for root initiation than for root elongation had not yet been discovered (Preece, 1993) .

Layering techniques were well-established (Bailey, 1891, 1896; Corbett, 1902). Layering methods in use when ASHS formed were tip layering, trench layering, mound (stool) layering, serpentine layering, and air layering. This area of propagation has changed little in the past century, except for modern use of polyethylene to wrap air layers. Because there have been so few changes in layering methods, the history of layering in the last hundred years is not described in this paper.

Grafting is another vegetative propagation technique that has changed little over the last century. The importance of vascular cambium alignment and callus growth between the scion and understock was well understood a century ago (Bailey, 1891, 1896; Corbett, 1902). One hundred years ago, propagators were t-budding, plate budding (including H-budding), flute budding, and chip budding. Grafting techniques included whip and tongue grafting, root grafting done as a form of whip grafting, saddle grafting, side grafting, splice grafting, veneer grafting, cleft grafting for topworking trees, wedge grafting, bark grafting, inlaying, seed grafting, and approach grafting (inarching). Plants were double-worked, suggesting an awareness of the importance of interstocks to overcome any localized graft incompatibility or to overcome weak and poor growth (Bailey, 1896). At that time, interstocks were called first scions; the second scion was grafted to the first scion. Propagators 
understood the importance of protecting and securing graft unions with resin and beeswax mixtures that might contain tallow, linseed oil, or turpentine; mixtures of pitch and beeswax that might also contain cow dung; alcoholic waxes; grafting clay that was a mixture of straw-free cow manure, clay and hair; waxed string and waxed cloth, and others. Because grafting also has changed relatively little during the last century, improvements to this technique are not discussed in this paper.

Among the main areas of advancement in vegetative propagation during the last 100 years are sanitation and propagation disease control, reduction or elimination of transpirational loss from cuttings, the discovery of plant growth regulators, greater knowledge of the roles of juvenility and phase change on vegetative propagation, knowledge of chimeras, micropropagation, and the use of vegetative propagation to escape specific viruses and other plant pathogens. The remainder of this paper focuses on these advancements. Because of space limitations, the section on sanitation and propagation disease control is centered on the development of the use of heat, especially steam, for partial disinfestation of propagation and other media and soils. Additionally, chimeras and their importance to vegetative propagation are not included in this paper. For detailed reviews on this subject, see Tilney-Bassett (1986) and Marcotrigiano (1997). It is not the aim of this paper to track the increasing number of species that have become commonly propagated vegetatively over the century. Mendel (1992) documented the increasing number of species that are now commonly propagated comparing the numbers mentioned in the first edition of Hartmann and Kester (1959) with the number in the 5 th edition (Hartmann et al., 1990). The increase from 148 species in 1959 to 242 species in 1990 was primarily in the number of ornamental trees, shrubs, and woody vines.

\section{USE OF HEAT FOR DISINFESTATION OF PROPAGATION AND OTHER MEDIA}

It was known in 1903 that fungi caused propagation diseases (Bailey, 1891, 1896), but apparently control was not widely known or used as indicated by its lack of mention in propagation textbooks and a USDA bulletin at that time (Bailey, 1891, 1896; Corbett, 1902). Even later, Brown (1916) did not advocate disinfestation measures but rather recommended using a sandy, well drained propagation medium containing no organic matter to prevent decay and avoiding standing water because it created an environment conducive to rot.

Although not mentioned in textbooks at the time, steam heating soil for disinfestation before planting was being used in some commercial operations in New England as early as 1899, as evidenced by the statement "Some market gardeners have practiced sterilization of their houses for three years" (Anonymous, 1902). This method was used by large growers at the time: "A lettuce grower who has a range of houses each about 300 feet long by 36 feet wide has recently treated them all by steam" (Anonymous, 1902).

At the beginning of the twentieth century, researchers recommended that the medium be heated to $82^{\circ} \mathrm{C}\left(180^{\circ} \mathrm{F}\right)$ for 1.5 to $2 \mathrm{~h}$ to kill pathogens effectively, though it was suggested that it would be safer to use a somewhat higher temperature (Anonymous, 1904). This temperature and time would have achieved greater kill of soilborne organisms than the shorter times and lower temperatures recommended today. Therefore, the concept of steaming propagation and other soils and media was just being developed when ASHS formed. The interesting history of its development has brought us to its common use today to partially disinfest media of harmful organisms, while sparing as many beneficial microbes as possible.

The first mention of the use of steam in a plant propagation textbook was by Kains (1916). He recommended that the soil at the bottom of the bed being steamed reach $99^{\circ} \mathrm{C}\left(210^{\circ} \mathrm{F}\right)$ for $30 \mathrm{~min}$ and that this would not only kill pathogenic fungi that infected propagules, but also would kill weed seeds and insects. However, Hottes (1918) stated that "heat disinfection has been only partly effective," indicating that it was probably not yet a widely accepted method of sanitation. Additionally, Hartley and Pierce (1917) tested various chemicals for disinfesting media because steam was expensive and heat "has proved inferior to other methods at all of the nurseries at which it has been tried."

In the last revision of his plant propagation book, Bailey (1920) devoted about $2 \frac{1}{2}$ pages to steaming soil with a direct quote from
Beinhart (1918). Beinhart (1918) referenced bulletins (published in 1909) that discussed steaming and therefore may have been unaware of the earlier publications on steaming soil (Anonymous, 1902; 1903; 1904). Beinhart (1918) recommended streaming for $30 \mathrm{~min}$ and wrote of a decreasing temperature gradient with increasing soil depth. Both Bailey (1920) and Hottes (1922) emphasized the importance of steaming soil to prevent propagation diseases. Therefore, steaming was clearly standard practice in the industry by the 1920 s. By 1938, it was recommended that soil be steamed to maintain temperatures of 95 to $100{ }^{\circ} \mathrm{C}$ (202 to $212^{\circ} \mathrm{F}$ ) for $60 \mathrm{~min}$ (Kains and McQuesten, 1938).

Laurie and Fueglein (1939) steamed greenhouse soil in which roses had been grown for $0.5,1,2,4$, or $6 \mathrm{~h}$. They then cultured the soil in vitro and found higher microbial counts from soil steamed for $<2 \mathrm{~h}$ than in nonsteamed soil and lower numbers than in nonsteamed soil when steaming duration was for 4 or $6 \mathrm{~h}$. It is likely the higher counts on the soils steamed for 0.5 to $2 \mathrm{~h}$ were related to the steam killing many, but, not all microbes. Those that remained could multiply with little competition. However, in the soils steamed for at least $4 \mathrm{~h}$, the counts were probably lower than in the control soil because they had been sterilized and microbes were only slowly being reintroduced.

The first mention of soil pasteurization, rather than sterilization, was by Adriance and Brison (1939). This book also contains the first mention of the use of a closed container heated by electricity to disinfest propagation media. They recommended raising the temperature of media to 66 to 71 ${ }^{\circ} \mathrm{C}$ for several hours and that with this lower temperature (compared to heating to nearly $100^{\circ} \mathrm{C}$ ): "Plants grow better in soil sterilized this way than when the soil is overheated." By 1955, it was known that nitrifying bacteria are killed by steaming at too high a temperature and that raising the temperature to $82{ }^{\circ} \mathrm{C}$ for 10 min should spare these beneficial microbes (Wells, 1955).

One of the most influential publications on sanitation of the propagation area and disinfestation of propagation media was a manual titled The U.C. System for Producing Healthy Container-grown Plants (Baker, 1957). In this manual, much emphasis was placed on the use of U.C. soil mixes, which were various combinations of fine sand and sphagnum peat. The authors recommended heating the soil to 82 to $100{ }^{\circ} \mathrm{C}$ for 30 min and found no toxicity problems in the U.C. mixes associated with elimination of beneficial microorganisms with high temperatures. They therefore recommended that growers err on the side of overheating because of the absence of toxicity. They stated that other types of soils, however should be heated to $82^{\circ} \mathrm{C}$ for $30 \mathrm{~min}$. Similarly, Hartmann and Kester (1959) recommended heating soil to $82{ }^{\circ} \mathrm{C}$ with steam for $30 \mathrm{~min}$ and cautioned that higher temperatures could be harmful to the soil.

In 1964, the idea of using aerated steam was introduced at a meeting of the International Plant Propagators' Society by Olsen (1964), who reported that with this technique sufficient pasteurization was achieved when the temperature of the medium was raised to $60^{\circ} \mathrm{C}$ for $30 \mathrm{~min}$. This recommendation also was made in all but the 1st edition of Hartmann and Kester $(1968,1975,1983)$ and Hartmann et al. $(1990,1997,2002)$ and remains standard practice in the plant propagation industry.

There were other advances in sanitation of the propagation area over the past century, including sanitation of tools, pots, benches, flat covers, etc. Additionally, chemical controls were developed and are widely used today.

Steaming and chemical methods for disinfestation of propagation media and soils, along with good sanitation practices, are now an important cornerstone for successful plant propagation.

Future methods to disinfest propagation and other growing media and soils may be quite different than what is practiced today. Perhaps field soils and greenhouse and other media will be disinfested by irridiation, sonication, or microwave radiation. A chemical as environmentally friendly as hydrogen peroxide (dioxide), which breaks down into water and oxygen, will likely be developed to disinfest media. In fact hydrogen dioxide has recently been used for disinfesting pots, benches, the surface of plants, etc. It or another chemical may be developed that can be used on soils in fields and within enclosed structures.

\section{THE DEVELOPMENT OF MIST AND FOG SYSTEMS}

Maintaining a high relative humidity around leafy cuttings or otherwise reducing transpiration was considered to be very important in 
1903 (Bailey, 1891, 1896; Corbett, 1902). Because mist and fog systems had not yet been invented, methods of reducing transpiration included reducing leaf area on cuttings by removal and/or cutting leaves in half; having a confined, humid atmosphere in which to root the cuttings by placing a glass cover over the propagation case, by inverting a jar over the cuttings or using a cloche; shading, including covering cuttings with newspapers during the hottest part of the day; keeping the soil moist; and frequent sprinkling of the tops of cuttings.

Botrytis must have been a problem in the high humidity cases that were covered with glass because of the stagnant, humid environment. Therefore, it was standard practice to tilt the glass plate or jar to allow for ventilation (Bailey, 1891, 1896). By 1920, cuttings were also rooted under muslin canopies or under wood slatted covers (Bailey, 1920). These covers provided shade and an atmosphere with a higher relative humidity than ambient conditions. Adriance and Brison (1939) recommended that "Frequent sprinkling of walls, walks, and beds in the greenhouse is necessary in order to keep the cuttings from drying and wilting." They stressed the need for strict sanitation if glass and other covers are used to reduce transpirational loss because these structures provided conditions that favored disease.

Apparently, mist for propagation was first used in 1936 in open spray beds by G.E.L. Spencer from the Imperial College of Tropical Agriculture, Trinidad, according to a personal communication from Spencer as cited in Evans (1951). Evans (1951) wrote that "the method did not apparently give satisfactory results and little further work was carried out." I could not find any publication on development of the mist system by Spencer and so conclude that this attempt only made it into the literature because of the 1936 communication with Evans (1951).

The earliest published report of the successful use of mist for propagating plants was an abstract by Raines (1940), followed by a second abstract (Raines, 1941). Experiments were conducted in "a moist chamber with facilities for subjecting its contents to a spray of water" (Raines, 1940). Using this chamber, leafy cuttings of Populus L. sp. (poplar), Salix L. sp. (willow) and other species produced many roots. The addition of nutrients to the spray also was mentioned, making this the first citation of aeroponics as well. However, Raines (1941) also wrote that "on the debit side, it must be noted that prolonged washing may be harmful to the plant."

By 1939, Gardner, a commercial propagator in Wisconsin, used a fog-like spray for rooting cuttings in a cloth-covered glass greenhouse (Gardner, 1941). The next year, he used a clothhouse at a different location. Originally, he used fixed nozzles but each nozzle covered only $1.86 \mathrm{~m}^{2}$ and breezes often blew the mist away from the cuttings. The next year (1940), the fixed nozzles used too much water and left dry strips. To overcome this problem, he used a rotating nozzle that covered the entire $5.1 \mathrm{~m}^{2}$ of the clothhouse. This nozzle misted the cuttings 2 to 4 times each minute. Although this is the first report of an intermittent mist system, continuous mist was still being used 12 years later (Wells, 1953). Gardner (1941) wrote that "on excessively hot days the moisture on the foliage dries with surprising rapidity and coverage by the spray should be at least every half minute. On hot days the cuttings wilted quickly after the foliage dried, but on cool days it was possible to shut off the water for considerable time without any noticeable effect." Using mist, he tested cuttings of 194 species and cultivars and only 13 genotypes did not root. Cutting rot was not a problem, but some of the roots that formed were initially brittle. This was not a problem if the plants were allowed to become more mature with larger root systems.

A greenhouse grower at the University of Kansas, James Reiter, also was working with mist propagation in 1941 (Fisher, 1941, 1943). Fisher (1941) reported that "this system has long been in use by some florists and nurserymen, but it is seldom used on the large scale employed at Lawrence" (Kansas). He did not say how long these growers had been using mist or where they learned about it. Fisher and Reiter ran their mist intermittently for only about 1 or $2 \mathrm{~h}$ on rainy or cloudy days, but continuously during sunny days. Fisher (1941) reported that local commercial propagators were "initiating its use in their establishments" based on the propagation successes with mist at the University of Kansas.

Snyder (1954) summarized the brief history of the use of mist in propagation. Based on the timing of the original reports by Raines (1940, 1941), Gardner (1941) and Fisher (1941, 1943), Snyder (1954) wrote "The timing on these reports indicate a simultaneous development of the concept by these men." Therefore, he did not credit any one individual with the invention of mist for propagation. As further evidence of Snyder's observation of independent discovery, Gardner (1941) wrote "I discovered an efficient and labor saving method of rooting green cuttings."

It would be interesting to determine if ancient horticulturists rooted cuttings in the mist generated by waterfalls, since many species in such an environment produce adventitious aerial roots. This may have been obvious to indigenous people and could have had a significant impact on their ability to propagate various food plants, such as some fruit crops.

In 1942 and 1943, Gossard (1944) conducted experiments with softwood cuttings of pecan under continuous mist. In 1942, "homemade mist heads were used," however, commercially-available mist nozzles in were installed by 1943 . Cuttings were rooted under mist in beds covered with cheesecloth to prevent wind from blowing the mist off the cuttings and to provide shade. A low percentage of the cuttings rooted under the excessively wet conditions provided by the continuous misting.

By 1947, O'Rourke and Moulton (1947) and O'Rourke (1949) were testing various mist nozzles. In particular, they were interested in a system that used air and water: "The compressed air blows over the water in such a way as to force it out as finely divided mist through three holes on the opposite side of the nozzle. As compared with other types of nozzles, these atomizers have given very little trouble in respect to clogging." Clogging of mist nozzles remains a problem today. Also O'Rourke (1949) was the first to write about problems associated with drips from nozzles: "The aperture becomes larger and unsymmetrical with continued use, so that a far great[er] portion of the water is lost by dripping." He also provided a "partial list of manufacturers supplying equipment for greenhouse humidification," listing 11 companies and thus suggesting good demand for humidification systems.

In the first meeting of the Plant Propagators' Society (now know as the International Plant Propagators' Society), Chadwick (1951) discussed controlling humidity during propagation. Humidifiers were "mechanical centrifugal atomizers powered by electric motors or water turbines, water under pressure, both air and water under low pressure and compressed air for the atomization of water." Therefore, it appears that he was considering both mist and fog systems for propagation. One system in use at the time was the Binks system of humidification (Binks Manufacturing Company, Chicago, Ill.). It functioned by "passing a stream of compressed air over a column of water so that the water is picked up and distributed in the form of a fine mist." This was used both commercially and at Ohio State University. It allowed propagators to maintain a $75 \%$ to $90 \%$ relative humidity depending on the cutting type and time of the year; therefore it was likely more fog-like than mist-like.

Intermittent (rather than constant) mist was in use by the early 1950s and was often controlled by humidistats (Hess and Snyder, 1953; Templeton, 1953). By 1953, speakers at the Plant Propagators' Society meeting discussed new methods to obtain an intermittent mist. Templeton $(1953,1955)$ first wrote about an electronic leaf in 1953 and an improved version in 1955. In this case, when the electronic leaf is wet, the water completes the circuit and the mist shuts off; when the water drys, the circuit is broken and the mist is turned on. Hess and Snyder (1953) developed a time clock system to control intermittent mist. Similar to modern time clock systems, theirs was composed of two timers. The first timer was used to turn the entire system on in the morning and off in the evening and the second timer controlled the on and off cycles of mist during the day.

Mist and fog were considered sufficiently important for vegetative propagation that by 1954, the Plant Propagators' Society had a roundtable on mist propagation. The first presentation was by Snyder (1954) who wrote that about eight publications on mist propagation appeared in print between 1940 and 1949 and more than 16 publications between 1949 and 1954, thus indicating the increased importance of the technique for vegetative propagation.

By 1954, there were three mist nozzle types: oil burner (whirl jet), 
self-cleaning, and deflection (Snyder, 1954). Most of the published papers still focused on continuous misting of cuttings, though intermittent mist also was being used. Propagators were aware that continuous misting used too much water and cooled the medium, making bottom heat necessary (Snyder, 1954). Hess (1954) showed that rooting of Ligustrum obtusifolium Regelianum (regal privet) increased from $73 \%$ under constant mist to $87 \%$ under intermittent mist controlled by time clocks to $93 \%$ when the intermittent mist was controlled by electronically. This was likely by use of an electric leaf, although this was not specified. Using commercial conditions, Ward (1954) found that cuttings rooted under intermittent mist were "more vigorous and responsive after potting than those propagated in tent houses or shaded frames." He also believed that constant mist was neither necessary nor practical. Time clocks, humidistats, an electronic leaf, and solar controls were all in use by 1954 to achieve an intermittent mist (Snyder, 1954).

Evans (1951) and Snyder(1954) wrote about problems with leaching of nutrients from cuttings and with leaves becoming chlorotic under mist. When Evans (1951) analyzed his Theobroma cacao L. (cacao) cuttings, he found that nitrates and phosphates leached during the first two weeks they were under mist, while potassium was leached continuously from the cuttings.

Despite leaching problems under mist, Snyder (1954) reported that rooting of Prunus serrulata Lindl., Juniperus chinesis L. 'Pfitzeriana', and Taxus ×media Redh. 'Hicksii' improved from 37\%, 2\%, and $12 \%$ rooting respectively in a Wardian Case to $87 \%, 94 \%$, and $74 \%$ respectively under intermittent mist. This demonstrates the major positive impact that the use of intermittent mist has had on vegetative propagation.

Intermittent mist remains widely used for rooting cuttings. In fact, Hartmann et al. (2002) devoted about six pages to the description and use of intermittent mist. Controls are basically the same as those of the 1950s and include timers, electronic leaves, screen balances, and photoelectric cells (Hartmann et al., 2002). However, in the fifth edition of their book, Hartmann et al. (1990) first wrote about the use of computerized controllers for intermittent mist systems. These systems "can be programmed to monitor air, media, leaf cutting temperature, light irradiance and vapor pressure differences between air and leaf; the environmental information can then be coupled to frequency and duration of mist or fog needed" (Hartmann et al., 2002).

The first reported use of fog for rooting of cuttings was published in the same time period as the original papers on the use of mist for propagation (Stoutemyer, 1942). He used "a Walton centrifugal humidifier or atomizer placed several feet above the rooting medium" and wrote that "a very fine mist or fog was produced which floated in the air for a long distance." Twelve of the thirteen species that he placed under fog had a higher percentage of rooting when compared to those placed under no humidification. Only Corylus L. hyb. 'Mildredensis' rooted better $(75 \%$ vs. $55 \%)$ without the fog. He also reported that cuttings under fog had a higher leaf retention rate and had fewer insect pests than those without humidification.

By 1954, Bailey (1954) was using fog in his commercial greenhouses to reduce transpiration from cuttings. He wrote the following about how the humidity was controlled: "Briefly, the Binks system is composed of a stream of air across the end of a tube filled with water. The water is completely atomized and all of it goes into the atmosphere. Drip and wet foliage below the nozzles are completely avoided." The system was controlled by an electronic humidistat to achieve $80 \%$ or $90 \%$ relative humidity for the first 2 to 3 weeks for conifer or deciduous cuttings, respectively, then $70 \%$ relative humidity until the cuttings rooted. He reported that in 1953, his propagators rooted successfully 180,656 out of 203,192 cuttings ( $89 \%$ ) using this system.

In the first edition of their plant propagation book, Hartmann and Kester(1959) briefly mentioned use of a fog-like mist and cited papers by Kiplinger (1946) and O'Rourke and Moulton (1947) about development of this system. However, even by 1975, the use of fog for propagation was limited: "Automatically operated devices which disperse a foglike mist are sometimes used in greenhouses" (Hartmann and Kester, 1975). Even in the fourth edition of their book, Hartmann and Kester (1983) devoted only one sentence to the use of fog for propagation, though they cited two important papers on this system (Milbocker, 1977; Milbocker and Wilson, 1979).
Milbocker(1977) spoke at the second meeting of the Eastern Region, International Plant Propagators' Society that I attended. I remember vividly his talk because it introduced me to fog propagation. He explained why fog was not used much at that time: "The consequential stagnant environment encouraged fungal growth resulting in an unpopular conception of high humidity propagation and it was nearly forgotten until 3 years ago." He applied fog in enclosed beds and found that with both ventilation and humidification, high temperatures (up to $46^{\circ} \mathrm{C}$ in summer) that others had encountered within similar humidified enclosures could be lowered and maintained below $38{ }^{\circ} \mathrm{C}$, which avoided plant damage. Milbocker and Wilson (1979) rooted cuttings from 30 species in his polyethylene-enclosures supplemented with fog. With adequate fan ventilation, $2-\mathrm{cm}$-wide vents along the entire length of each side, or the use of $15 \%$ shade cloth along one end of the enclosure, problems associated with Pythium sp. could be reduced to the same levels as achieved with weekly fungicidal drenches (Milbocker, 1977; Milbocker and Wilson, 1979).

By 1983, Milbocker (1983) wrote that "ventilated high humidity propagation is understood by relatively few propagators." However, equipment for fog propagation systems was, by then, "available from several manufacturers as automated and reasonably reliable systems for commercial propagation." One of the most complete articles on fog propagation was written by Press (1983). He detailed the design of a fog propagation system and listed numerous advantages of using fog over mist, including that fog does not make the rooting medium and leaves on the cuttings too wet, that fog uses about $25 \%$ less water than mist, that there is more oxygen available in the medium under fog than mist, that disease is less than with mist, and that cuttings root in a shorter time under fog than mist.

Following the publication of the papers by Milbocker (1977 and 1983) and Press (1983), there was much greater acceptance of fog than previously encountered. In his plant propagation book, Macdonald (1986) devoted more than six pages to fog propagation, listing eight advantages of fog over mist and only two limitations of a fog system. These were less flexibility in a fog propagation house because the whole area is filled with fog droplets, though this can be rectified by installing a polyethylene curtain to partition the propagation house, and the fact that it can become quite hot $\left(>46^{\circ} \mathrm{C}\right)$ in a fog house. By their fifth edition, Hartmann et al. (1990) devoted nearly three pages to fog. By the late 1980s fog was a more standard method of reducing transpiration than previously and is now an important method for commercial plant propagation.

In the future, systems to reduce cutting transpiration likely will be controlled more precisely than at present. Propagation cases are being developed that allow propagators to control the moisture of the medium independently of atmospheric moisture (Saha et al., 2001). Other chambers are being developed commercially where sunlight or electric lamps can be used, as well as supplementation with $\mathrm{CO}_{2}$ during the rooting process. Environmental control in small chambers and in larger greenhouses will likely be improved in the future so that humidity levels can be varied to match the needs of cuttings during and after the rooting process. Mist will likely continue to be used widely, but fog propagation will continue to grow in popularity. If an ideal antitranspirant is developed that is not phytotoxic and will effectively stop transpiration but not photosynthesis, perhaps the need for mist, fog, or other high humidity environments can be eliminated, making vegetative propagation more efficient and less costly.

\section{JUVENILITY}

Goebel (1900) was the first to discuss the concept of juvenility as it relates to propagation. He wrote "Different species behave differently in this respect; many are not able to produce new roots on detached twigs, and one and the same plant may even behave differently at different ages. The juvenile form of the Cupressineae, for example, roots very easily, the twigs of the older plants do so with difficulty." Plant propagation publications make no further mention of this for nearly another 30 years, suggesting that the influence of juvenility on rooting of cuttings was not common knowledge 100 years ago.

Although they did not mention juvenility or greater ease of rooting, some propagators were using more juvenile portions of adult plants 
to produce softwood shoots. Bailey $(1891,1896,1920)$ wrote about producing plants from chips of tree trunks, knots on Olea europaea L. (olive) and Platanus L. (plane-tree) trunks, and sprouts from saw-logs of Ulmus L. (elm) and Fraxinus L. (ash) while in water. Softwood shoots from these portions of plants should exhibit juvenile traits, especially if the original tree was seed-propagated. Brown (1916) wrote about truncheons and their use in Europe for propagating olive. Some European propagators cut 1 to $7.5 \mathrm{~cm}$ diameter branches (truncheons) from trees, split the smaller ones and quartered lengthwise the larger stems. These were planted horizontally with the split side down and covered with 7.5 to $10 \mathrm{~cm}$ of medium in the early spring. The buds elongated through the surface of the medium and these new, softwood shoots rooted in a manner similar to layered shoots. Although not recognized as taking advantage of juvenility, the truncheons were from within the cone of juvenility of the trees.

Apparently the greater ease in rooting juvenile plants was first clarified by Gardner (1929). In this landmark paper he compared rooting response from 21 tree species that ranged in age form one year to $>2$ years. In all species, except Prunus persica (L.) Batsch. (peach), rooting was best if cuttings were made from 1-year-old seedlings. He also reported that the increased rooting response was unlikely related to a "root-producing substance carried over from the seed" because when he cut back year-old apple seedlings to the ground and harvested cuttings from the regrowth, these cuttings tended to root as well or better than from year-old seedlings. He even tried soaking and injecting apple cuttings with extracts from germinating apple seeds and found that these soaks failed to increase rooting. He thought that the increased rooting response was related to "nutritional and anatomical differences within the plant."

Juvenility was first mentioned in a plant propagation book in 1931 (Laurie and Chadwick). They described juvenile forms of leaves and stated that "juvenile forms may be preserved by vegetative propagation." However, they failed to mention that juvenile forms of plants rooted more easily than adult forms of plants. Hottes (1949) wrote that "Rooting somewhat decreased with the advancing age of the plant from seed." This was the first description in a plant propagation book of the effects of juvenility on rooting of cuttings. Wright (1955) wrote "As a general rule cuttings from young plants root best, but, if older plants are cut back hard, very often they can be induced to produce suitable material." Mahlstede and Haber (1957) devoted an entire section to the greater rooting response of more juvenile over adult cuttings and mentioned that juvenility can be maintained by layering, cutting trees to the ground, and using shoots from induced sphaeroblasts. Likewise, Hartmann and Kester (1959) included a section on juvenility and the ease of rooting associated with young plants. Therefore, by the 1950s the greater ease of rooting cuttings from juvenile individuals compared to from adult plants was well known.

In their relatively recent review, Hackett and Murray (1997) concluded that maturation in plants is a multistep process that can be regulated at the transcription level and that there are both biochemi$\mathrm{cal}$ and molecular markers that are expressed preferentially in either juvenile or adult phase tissues.

Del Tredici (1998) listed four types of natural rejuvenation in woody plants: root suckering, stolons, natural layering, and basal suckering. Hartmann et al. (2002) cited additional methods to rejuvenate plants or to obtain juvenile-phase cuttings or explants for micropropagation, including: collecting propagules that exhibit juvenile characteristics; collecting material from within the cone of juvenility (the oldest parts of seed-propagated plants); establishing hedge rows that are pruned to maintain juvenility; using serial propagation, such as grafting mature phase scions repeatedly onto consecutive generations of seedling rootstocks; subculturing shoot explants in vitro for a time; and applying plant growth regulators, such as gibberellic acid, to adult-phase stock plants.

Hartmann et al. (2002) also mention collecting shoots from sphaeroblasts, similar to what Bailey $(1891,1896,1920)$ wrote about previously. There have been a series of reports where, rather than sphaeroblasts being excised to produce softwood cuttings, branches or sections of the main trunks of trees have been cut into sections, placed horizontally on suitable media, often under intermittent mist or fog for the purpose of producing softwood cuttings for rooting or micropropagation (Fishel et al., 2003; Henry and Preece, 1997a, 1997b; Preece et al., 2001, 2002; Van Sambeek et al., 1997a, 1997b; Van Sambeek and Preece, 1999; Vieitez et al., 1994). Fishel et al. (2003) found that when sectioning the trunk of Quercus rubra L. (northern red oak), that softwood shoots from the lowest section rooted best and that there was a significant linear decrease in rooting of softwood shoots forced from stem sections as their original distance from the bottom increased. This is consistent with a gradually increasing maturation gradient along the trunk. Interestingly, shoots forced from the lowest sections rooted better than those from stump sprouts that grew in the field, possibly indicating that the forcing environment also plays an important role in subsequent rooting.

The propagation dilemma caused by phase change will continue to be important to propagators in the future. Researchers are unable to evaluate sufficiently a plant until it is mature. At this stage, the ability for efficient vegetative propagation by rooting cuttings and micropropagation is often lost. New ways to rejuvenate plants for vegetative propagation will be developed. As the genetic and physiological bases for phase change become more clear, more focused methods of rejuvenation will be developed. Treating cuttings or stock plants with rejuvenating chemicals would be ideal, but phase change may be too complex for this solution. If such chemicals or other methods were developed, it would further revolutionize vegetative propagation of woody and other important plant species.

\section{AUXINS AND ROOTING OF CUTTINGS}

Julius Sachs was a careful observer of plants and reached conclusions over a century ago that have had important ramifications for plant propagation. Sachs (1879) thought that very small amounts of special substances that were produced by the plant caused the formation of shoots, leaves, roots, and flowers. He indicated that the root forming substance came from the leaves of the plants and moved downward initiating roots. He also thought that a shoot forming substance came from the root and moved upward in the plant. It is interesting that auxins and cytokinins were predicted with such accuracy so long ago.

Loeb (1917a, 1917b) conducted a series of experiments on stems of Kalanchoe pinnata (Lam.) Pers. before the discovery of auxins. He observed that when he partially or totally defoliated stems and laid them horizontally, leaves and apical buds inhibited outgrowth of more basal axillary buds, caused stem curvature (positive phototropism), and caused the formation of adventitious roots on the stems. He proposed that substances were moving basipetally out of the leaves and apical buds that were responsible for these growth and developmental phenomena. He thought that it was possible that the same substance(s) could be causing these responses, or that there were shoot inhibitory substances that accompanied the root-forming hormones. It is interesting that what he called hormones later were proven indeed to be hormones. These auxins ultimately would be used to stimulate rooting of cuttings.

By 1929, Went (1929) conducted experiments on rooting stem cuttings of Acalypha wilkesiana Müll. Arg. (three seeded mercury or copperleaf). $\mathrm{He}$ found that if both leaves and buds were retained, the cuttings rooted well, but if both buds and leaves were removed, rooting was suppressed. Rooting did occur if leaves, but not buds, remained on the cuttings. In a pair of experiments, he "placed a good many leaves with their stalks in a small quantity of water. To prevent evaporation, they were covered with a globe. Every day the water was boiled down at low pressure and replaced by fresh water to repress bacterial development." He mixed the concentrated boiled down juice with agar and placed cuttings on the agar. He found that the concentrated juice from copperleaf leaves stimulated rooting of Acalypha cuttings, as well as rooting of Carica papaya L. (papaya). However, the concentrated juice from papaya leaves was more of a stimulus to papaya cuttings than the extract from the Acalypha leaves. He also found that diastase (the malt from germinating barley seeds) also stimulated rooting. He concluded that there was a root producing substance in the concentrated juice from the leaves and in the diastase. He apparently thought that this was a single substance: "A special rootproducing substance, not specific, and heat-resisting, is shown to be extractable from leaves and germinating barley, and to have the effect of starting the development of new roots. It seems to be transported by the phloem and is formed in leaves and sprouting buds, and occurs in considerable quantities in the branches." 
Kögl (1933) named two compounds that were active in the Avena curvature test: auxin $a$ (isolated from human urine) and auxin $b$ (isolated from corn germ oil). By 1934, Kögl et al. (1934a, 1934b) had isolated and identified indole-3-acetic acid (IAA) from urine samples that showed very high auxin activity. According to Crocker et al. (1935), Fritz Kögl was the first to use the name auxin.

By 1934, Went (1934) was calling the rootforming phytohormone that he was working with rhizocaline, which he found in extracts of rice polishings. The first mention of rhizocaline was by Bouillenne (1933) in a study on rooting Impatiens balsamina L. Hottes (1934) wrote about the work of Bouillenne and Went on rhizocaline in his propagation book, indicating that there was a general awareness of the importance of this research for vegetative propagation.

Went (1934) found similar rhizocaline activity in urine fractions that he obtained from Kögl: "However, it seems likely that some of these factors also are extractable from urine as some of the first urine extractions give an excessive rootformation, up to 88 roots per 10 plants (controls 16)." Went (1934) mentioned auxin by name, but he did not write whether he believed rhizocaline and auxin to be the same. He established an etiolated pea seedling shoots - rhizocaline bioassay, with root numbers increasing linearly with rhizocaline concentration. Based on this, he also developed a "root or rhizocaline unit (RU)" defined as "a solution contains one RU if it produces 1 root when tested in the described way."

Thimann and Went (1934) tested the RU activity of a water extract of rice polishings (given the activity of $1 \mathrm{RU} / \mathrm{mg}$ ), urine, wheat germ oil, pollen and leaves of various species, and etiolated pea buds and shoots. Most samples tested, except for Helianthus L. sp. (sunflower) and Prunus laurocerasus L. (cherry laurel) leaves, had at least some RU activity. They focused on comparing a partially purified extract from Rhizopus suinus culture medium with another urine-derived extract "to determine whether the properties of the two hormones were similar or not." They thought that the two were somewhat different, but "it is at least safe to conclude that the two hormones are extremely closely related. It is hoped to obtain conclusive evidence as to their identity or difference at a later date."

Thimann and Koepfli (1935) were aware that Kögl et al. (1934a) had found that $\beta$-indolyl-acetic acid was one of the active hormones in urine. Thimann and Keopfli (1935) were, apparently, the first to report that synthetic preparations of this substance were "fully active in promoting root formation" of etiolated pea cuttings. However, they also tested $\beta$-indolyl-propionic and indole- $\beta$-carboxylic acids, which did not stimulate rooting or promote growth, though they saw slight activity from concentrated solutions of $\beta$-indolyl-propionic acid if they recrystallized it. In contrast, Hitchcock (1935a) found that lanolin preparations of indole-3-n-propionic acid (obtained from the Eastman Kodak Company) stimulated rooting in a manner similar to a synthetic preparation of $\beta$-indolyl-acetic acid (also in lanolin) "particularly on potted plants of [Lycopersicum esculentum Mill.] tomato and [Tagetes erecta L.] african marigold."

Thimann and Koepfli (1935) were intrigued that the same compound ( $\beta$-indolyl-acetic acid) could stimulate both cell elongation and rooting of cuttings and wondered about the mechanism that allowed it to do both.

Cooper (1935) tested $\beta$-indolyl-acetic acid in lanolin on cuttings of Citrus lemon (L.) Burm.f. (lemon), Lantana L., Ficus L. (fig), Acalypha, and Tradescantia $\mathrm{L}$. and found that the auxin stimulated rooting of in-leaf and leafless lemon cuttings. Without the auxin, the leafless lemon cuttings did not root. He also found that auxin treated cuttings of Lantana, fig, and Acalypha produced more roots than the controls, and that auxin even stimulated rooting of Tradescantia internodes. He concluded that the auxin not only stimulated cuttings to root that would not normally root, but also stimulated "increased rooting with cuttings that will root when untreated."

Zimmerman and Wilcoxon (1935) tested nine new chemicals for auxin-like activity. Although all stimulated root initiation on several species, they wrote "alpha-naphthaleneacetic acid (NAA) and indolebutyric acid (IBA) were especially effective for initiating roots on both stems and leaves." It is interesting that only about two years after IAA was identified and isolated by Kögl et al. (1934a, 1934b), these two important synthetic auxins already had been synthesized and tested. This was a major breakthrough for propagation by cuttings because these two compounds are the most commonly applied auxins in the propagation industry today.

Zimmerman and Wilcoxon (1935) also reported that "under comparable conditions similar concentrations of indoleacetic acid were not as effective for producing roots as either indolebutyric or $\alpha$-naphthaleneacetic acid." Hitchcock (1935b) had similar results and reported on the high rooting activity of IBA, but a lower activity for NAA "from the standpoint of good rooting response, indolebutyric acid was the most effective, followed in decreasing order by indoleacetic and phenylacrylic, phenylacetic, naphthaleneacetic, phenylpropionic, and indolepropionic acids."

The authors of these previous papers applied auxin in lanolin, which is not practical in commercial propagation. Hitchcock and Zimmerman (1936) were the first to test solutions of auxin (IAA, IBA, NAA, and indolepropionic acid (IPA)) dissolved in a small amount of alcohol and diluted in water on woody cuttings. They found that these alcohol/water solutions were "from 100 to 500 times more effective than lanolin preparations" and that an alcohol/water solution "of the growth substance was particularly effective on Ilex [L.], Taxus [L.], Hibiscus [L.], and Pachysandra [Michx.]." Using similar alcohol/water solutions, Skinner (1937) reported that IBA "gave an average rooting increase of 24 per cent over untreated cuttings" (of Ericaceous plants) and that IBA was much more effective than IAA for stimulating root initiation.

Greatly intrigued by previous results with various auxins, Chadwick and Kiplinger (1938) tested the effects of dusts (talc forumlations?) named Auxan and Rootone and/or alcohol/water dilutions of IBA on more than 100 ornamental plants. They found that the solutions were somewhat more active for rooting than the dusts and that spraying the solutions on the tops was not nearly as effective as soaking the bottoms of the cuttings. They recognized that auxin applications would not stimulate rooting in some plants that are difficult to propagate by cuttings.

Auxins became commercially available quickly, which is not a surprise considering how much the discovery of auxins revolutionized cutting propagation. Kains and McQuesten (1938) wrote "The right to place one of them upon the market has been officially granted by the Boyce Thompson Research Foundation, Inc., to Merck and Co., Inc., of Rahway, N.J., under the trade name of Hormodin A. Other growth substances are also being officially sanctioned by the Foundation under different letters." Chadwick and Kiplinger (1938) also stated that they obtained Auxan and Rootone from the Chemicals Limited, Canada, and the American Chemical Paint Co., Ambler, Pa., respectively. None of the authors gave the active ingredient(s), though formulations with the trade names Hormodin and Rootone remain available commercially. Today, Hormodin contains IBA and Rootone contains IBA, 1-naphthaleneacetamide and the fungicide tetramethyl thiuramdisulfide (thiram). These may or may not be the same as earlier. That these compounds were available so early to commercial propagators indicates a very rapid transfer of revolutionary technology from scientists to growers.

Auxins are now used regularly by commmercial propagators and IBA and NAA are still the most effective auxins for rooting (Dirr, 1992). It is possible that a new class of compounds or new chemicals will be developed that stimulate rooting more effectively than auxins, but this appears unlikely since we have been using IBA and NAA for rooting cuttings for about 70 years. Rather, I expect that we will learn how to make cells in cuttings more sensitive to auxins. If this can be done, it could further revolutionize cutting propagation. Many species are very difficult to root, even with auxin application. Additionally, many species can be rooted only if the physiological condition of the cuttings is correct, e.g., softwood cuttings of many woody plants root much more readily than hardwood cuttings. It appears that these species or cuttings may lack the ability to recognize auxin, do not have the signal transduction pathway for auxin to stimulate rooting, or contain inhibitors to the rooting process. As we learn more about the molecular basis of rooting, perhaps cuttings can be pretreated or cotreated so that they will respond to auxin applications with high rooting percentage. It would be of great help to growers if more species could be rooted easily and if all temperate woody species could be propagated readily by hardwood cuttings. Hardwood cuttings are desirable because they can be taken, treated and placed in an environment suitable for rooting during the winter season when field work is minimal and labor is in surplus. 


\section{MICROPROPAGATION}

An important early paper establishing in vitro technique for the propagation of plants was published by Knudson (1922), wherein he presented a method for surface disinfestation of orchid seeds, and found that sugar was necessary for the seeds to germinate in vitro without a mycorrhizal association. This system is still in use for germinating orchid seeds. Hartmann and Kester (1959) wrote about aseptic culture only for germinating seeds. Later, Hartmann and Kester (1968) devoted a whole chapter to the subject, used the term micropropagation, and wrote about in vitro clonal multiplication of plants.

White (1934) was the first to report substantial growth of a plant organ (roots) in vitro and was able to maintain their growth for more than one year and 52 transfers to fresh medium. The greatest growth occurred on one tomato root that grew from $10 \mathrm{~mm}$ long to more than 400,000 $\mathrm{mm}$ within this year. Before that time, vegetative explants either simply survived in vitro or grew in very small increments. The combination of three classes of ingredients in the medium were credited with the excellent growth observed by White (1934): balanced salts, sucrose, and brewers' yeast. Soon after, Gautheret (1939) and Nobelcourt (1939) reported the successful growth of plant callus tissue cultures.

Using Nicotiana tabacum L. (tobacco) stem explants, Miller and Skoog (1953) found that the addition of adenine to the tissue culture medium stimulated the formation of buds (this is one of the earliest reports on shoot organogenesis in vitro) and that IAA was inhibitory. Later, Jablonski and Skoog (1954) reported that although IAA stimulated "enormous enlargement of the cells," cell division was lacking. In fact, Naylor et al. (1954) found that IAA stimulated nuclear divisions, but not cytokinesis (the process of cytoplasmic division). Miller and Skoog (1953), reported that the inhibitory effect of IAA on cytokinesis could be overcome by high concentrations of adenine or guanine.

Jablonski and Skoog (1954) reported that water extracts from vascular tissue of tobacco, malt extract, liquid Cocos nucifera L. (coconut) endosperm, and an extract from solid coconut endosperm all induced cell division. Similarly, Miller et al. (1955b) found that autoclaved DNA from herring sperm and from calf thymus was active in stimulating cell division in tobacco wound callus tissue cultured in vitro. This activity was not present if the DNA was not autoclaved.

From $100 \mathrm{~g}$ of autoclaved DNA, Miller et al. (1955b) extracted about $30 \mathrm{mg}$ of a crystalline material, calculated its original formula as $\mathrm{C}_{10} \mathrm{H}_{9} \mathrm{~N}_{5} \mathrm{O}$, and suggested that it be named kinetin. This was the first cytokinin discovered, and Miller et al. (1955b) stated that "It is physiologically active at very great dilutions but only in the presence of auxin (added IAA). The lowest concentration tested, $0.01 \mathrm{ppm}$, was effective." A little later, Miller et al. (1955a) correctly found "that kinetin most probably is 6-furfurylaminopurine." In a note added in proof, they stated that "The biological activity of synthetic kinetin now has been found to be the same as that of the isolated substance in tests on tobacco tissues." This activity was confirmed a year later (Miller et al., 1956). In this later paper, they described chemical synthesis of kinetin from adenine and proposed the generic term kinin for this class of substances that stimulate cytokinesis. To avoid possible confusion with kinins in animals, we now know this class of compounds as cytokinins.

The cytokinin most commonly used for micropropagation today is benzyladenine (BA, benzylaminopurine, BAP), first mentioned by Strong (1958). He included BA in a list of eight compounds with activity similar to kinetin in the tobacco callus bioassay. Today, in most in vitro systems, BA has greater activity than kinetin. Strong (1958) also found 1,3-diphenylurea to have activity lower than kinetin, though a substituted phenylurea compound, thidiazuron (TDZ, N-phenyl-N'1,2,3-thidiazol-5-yl urea) is now known to have tremendous cytokinin activity on a number of species, especially woody plants (Huetteman and Preece, 1993).

An adventitious system for obtaining plants, other than the previously mentioned shoot organogenesis, is somatic embryogenesis. This was first reported by Reinert (1958) and Steward (1958). Somatic embryogenesis is distinctly different from organogenesis because organs, such as shoots and roots, have one primary pole or growing point, whereas embryos are bipolar structures with both shoot and root meristems. Generally speaking, neither adventitious system of obtaining plants (shoot organogenesis or somatic embryogenesis) is used widely in commercial micropropaga- tion. One reason is that sometimes, adventitiously regenerated plants produced in vitro look or behave differently than the original stock plant from which the explants were obtained.

There are many reviews on the variation among adventitiously regenerated plants from in vitro cultures that provide a historical perspective (Bouman and de Klerk, 1997; Larkin and Scowcroft, 1981; Scowcroft and Larkin, 1982; Sheridan, 1974; Skirvin, 1978). In 1981, Larkin and Scowcroft (1981) introduced the term somaclonal variation to describe this phenomenon.

Bouman and de Klerk (1997) stated that somaclonal variation can be avoided by not having repeated regeneration steps, having a very short callus phase (even avoiding unorganized callus), avoiding protoplasts, and using meristematic tissues as the explant source. However, culturing apical meristemic domes can be quite difficult and results in a low rate of success (Murashige, 1974). Rather, larger explants that will give rise to axillary shoots, such as shoot tips, buds, and nodes are commonly used for clonal micropropagation because there is a great reduction in somaclonal variation compared to adventitious regeneration of shoots or somatic embryos (Preece, 1997).

One of the most significant breakthroughs for successful clonal micropropagation was the development of a superior defined medium, known as Murashige and Skoog (1962) medium (MS). This continues to be perhaps the most commonly used medium in tissue culture today. Although originally developed for tobacco callus cultures, it has proven to be an excellent medium for a multitude of plant species. Three other media that are frequently used in research and commercial laboratories for the clonal micropropagation of woody species are Anderson's revised medium primarily used for members of the Ericaceae (Anderson, 1984), Woody Plant Medium (WPM, Lloyd and McCown, 1980), and Driver and Kuniyuki (1984) walnut (DKW) medium (for corrected recipe, see formula for DKW-C in McGranahan et al., 1987).

Murshige (1974) defined three major stages of the tissue culture method: Stage I: establishment of the aseptic culture, where the explant is induced to grow. For clonal micropropagation, this includes initial outgrowth of preformed buds. Stage II: multiplication of propagula, where axillary shoots are induced to proliferate for clonal multiplication. His final stage was Stage III: preparation for reestablishment of plants in soil. Subsequently, many working in clonal micropropagation have added Stage 0 : care and preparation of the stock plant. This is because of the increased recognition of the importance of the condition and genetic makeup of the plant from which explants are made. Additionally, many now subdivide Murshige's Stage III into Stage III: rooting (or pretransplant), where the objective is to obtain roots on microshoots; and Stage IV: acclimatization of the rooted plantlets to the ambient environment in a greenhouse or field. Frequently, Stage IV can be the most problematic stage of the entire micropropagation process as the plants slowly acclimatize to the lower relative humidity, ex vitro environment (Preece and Sutter, 1991; Preece, 2001). However, Stages III and IV can be combined by rooting microshoots ex vitro at the same time that they are acclimatized, as in Murshige's original Stage III.

Commercial micropropagation is now an important component of the vegetative propagation industry. Recently, it was reported that "a total of 93 commercial laboratories (in the U.S.) are currently active in 28 states, down from 111 in 1996, and most still are located near important production areas of the horticultural industries they serve"(Zimmerman and Griesbach, 2001). Additionally, they reported "total production for 2000 was 130,613,000 units (shoots, plants, bulbs, minitubers), up from $120,862,000$ units in 1996."

Commercial micropropagation will continue to be important for production of clonal plants. I expect that the biggest breakthroughs will be in the automation of the process to reduce costs, as well as in storage of cultures or explants. Micropropagated plants are expensive because they are extremely labor intensive. Bioreactors and machines that automatically cut and subdivide cultures and transfer them to fresh medium, continue to be developed. Additionally, various new ways to store cultures or explants are being studied. There are considerable labor and materials expended to maintain cultures during times of the year when there is no demand for plants. Refrigerated storage of cultures under light and encapsulation of nodal sections in alginate gels continue to be tested. This increased efficiency will continue to solidify clonal micropropagation as an important sector of the plant propagation industry. It is unlikely 
that micropropagation will totally replace other methods of vegetative propagation because of cost, efficiency, less capital investment, and ease of various macropropagation methods.

\section{ESCAPING PATHOGENS USING VEGETATIVE PROPAGATION TECHNIQUES}

An interesting use of vegetative propagation technology has been in the production of plants that are free from specific pathogens, especially viruses. The first report was an abstract by Holmes (1948), followed by a complete paper (Holmes, 1955). During 1946, Dahlia pinnata Cav. 'Rhythm' (dahlia) showed a severe outbreak of spotted wilt (caused by a virus). Holmes (1948) rooted tip cuttings from emerging shoots. Most of the rooted cuttings showed no symptoms when potted and grown. These plants were grown to flowering in a greenhouse and in the field and did not show spotted wilt symptoms. Holmes (1948) assumed that the removal of the diseased tissues was the reason for the lack of disease symptoms, although he was aware that the cuttings were sufficiently small and vigorous to escape the virus. By 1955, Holmes (1955) wrote "Apparently the causative virus does not move freely toward the growing tips of dahlia plants but lags behind the growth of the stem."

Also working with dahlias, Morel and Martin (1952) excised 250 $\mu \mathrm{m}$ apical meristematic domes, typically including two visible leaf primordia from plants with dahlia mosaic symptoms, and placed them in vitro on nutrient medium supplemented with glucose. Some of the apical meristematic domes grew, but none produced roots. They then grafted 1 to $2 \mathrm{~cm}$ long shoots onto young, virus-free plants. These grafted plants developed normally, without dahlia mosaic symptoms. In this case, two different vegetative propagation techniques were used: apical meristem tissue culture and grafting.

Later, also using 100 to $200 \mu \mathrm{m}$ apical meristems, Morel and Martin (1955) successfully produced Solanum tuberosum L. (potato) plants without virus symptoms. In fact, Kassanis (1957) using apical meristematic propagation produced some initial virus-free plantlets of 'King Edward VII' potato. These were further vegetatively propagated to produce a large number of plants that in field trials had an increase in yield of $>10 \%$ compared to other stocks. Kassanis (1957) initially cultured 250 apical meristematic regions, 177 of which survived, from which four plantlets were obtained, three of these were free from virus, for a $1.2 \%$ success rate.

Apparently, many plant propagators were unaware that vegetative propagation techniques were being tested to escape pathogens. Adriance and Brison (1955) wrote that "The cause of virus diseases is not known; hence no treatments are recommended that will make infected seeds safe for planting." Hartmann and Kester (1959) wrote about taking tip cuttings from tall plants to escape Verticillium and Phytophthora and the use of heat therapy to rid plants of pathogens, such as bacterial soft rot, but not about their use to escape viruses.

It was recognized early that plant thermotherapy prior to excision of apical meristematic regions will increase the success rate for producing plants that are free from certain viruses at times when culturing of apical meristematic regions fails to produce this result (Thompson, 1956; Quak, 1957). These researchers grew the plants at 35 to $38^{\circ} \mathrm{C}$ for a while before excising apical meristematic regions. Applying thermotherapy to sprouted potato tubers and tissue cultures, Thompson (1956) was able to produce a few potato plants free from potato virus $\mathrm{Y}$, but not virus $\mathrm{X}$. By 1974, heat therapy was accomplished by using hot water or hot air in combination with micropropagation of the apical meristematic region (Mullin et al., 1974). These authors grew Fragaria L. sp. (strawberries) with strawberry mild yellow edge (SMYE) viruses for 6 weeks in a 36 ${ }^{\circ} \mathrm{C}$ growth chamber before excising 0.3 to $0.8 \mathrm{~mm}$ meristematic tips with leaf primordia. The result was that $33 \%$ to $75 \%$ of the resulting plants were SMYE-free according to leaf insert graft indexing to indicator strawberry plants.

Barnett et al. (1975) used both heat $\left(40^{\circ} \mathrm{C}\right)$ and cold $\left(10^{\circ} \mathrm{C}\right)$ therapy on virus infected Trifolium repens $\mathrm{L}$. (white clover) prior to taking 1.5 to $2.5 \mathrm{~cm}$ long stolon tip cuttings or culturing the apical meristematic domes from stolons that contained one or two leaf primordia. They found that cold therapy "provided plants free of clover yellow vein virus (CYVV), whereas cuttings from plants at the hot temperature provided plants free of alfalfa mosaic virus, white clover mosaic virus and CYVV." They also found, when comparing the use of apical meristematic domes and small stolon cuttings that "this technique worked with all the clover viruses investigated and resulted in a higher percentage of virus-free plants than the use of stolon tip cuttings."

In an interesting early review of the technology, Baker and Phillips (1962) wrote about using shoot tip culture propagation (the apical meristematic dome plus leaf primordia, typically 0.2 to $1 \mathrm{~mm}$ long for carnation) to escape bacterial, fungal, and viral pathogens in ornamentals. They even cited Holmes' 1956 paper, where 4-mm-long tips from aspermy virus infected Dendranthema grandiflora Tzevelev. (chrysanthemum) were grafted to obtain plants free from virus symptoms. Baker and Phillips (1962) wrote extensively about the problems associated with blocks of stock plants becoming infected: "A period of 3 to 4 years may elapse between initiation of a nucleus block and the actual production of flowers by a commercial grower. Obviously, pathogens may be reintroduced during this period." They suggested that this can only be accomplished by using plants free from pathogens initially and "From a theoretical standpoint, this should be accomplished by conventional sanitation procedures. The potential success of this endeavor is yet to be realized fully in practical application." Operations, such as Yoder Brothers, in Ft. Myers, Fla., and the Foundation Plant Materials Service, in Davis, Calif., have strict sanitation procedures for their plants that have been shown to be free from specific pathogens. These procedures include screening systems to keep out insect vectors. In fact, Mullin, et al. (1974) maintained strawberries that had received heat therapy and were propagated using apical meristematic regions, free from detectable graft transmissible diseases for seven years in a greenhouse and a screenhouse. However, for most growers with stock blocks in greenhouses or fields, sanitation, preventative sprays, and a careful vigil must be maintained to avoid new infections and to determine if these valuable stock plants have been invaded by pathogens.

An important step in the production of plants free from specific pathogens was the development of the enzyme-linked immunosorbent assay (ELISA) for the detection of viruses by Voller et al. (1976) and Clark and Adams (1977). This eliminates the need to graft onto indicator plants to detect viruses when reliable ELISA tests are available for the specific virus of interest.

Hartmann and Kester (1968) wrote about using the meristematic region to escape pathogens: "This technique is used to produce a pathogen-free stem cutting, since the tip is usually free of bacteria, fungi and viruses." They continue to include this important technology in subsequent editions of their plant propagation book (Hartmann and Kester, 1975, 1983; Hartmann et al., 1990, 1997, 2002).

This is an excellent example of how methods of vegetative propagation can be used, not only to multiply plants clonally, but to produce plants that tend to grow better and be more productive. It has been well known for hundreds of years that clones can decline in vigor and even become extinct (Hartmann and Kester, 1959). Development of the technology to escape viruses and other pathogens has increased productivity and profitability of a great number of plant species.

I believe that thermotherapy combined with micropropagation of apical meristematic regions will continue to be used to escape viruses and other pathogens. In the future, perhaps more efficient and less costly methods will be developed to produce pathogen-free plants. Ideally, a systemic solution that is not expensive and could be sprayed on plants to eliminate pathogens would be superior to the cost and labor involved in using thermotherapy and tissue culture. Perhaps such a class of chemical substances will be developed. Plants have been genetically transformed to make them resistant to or tolerant of specific viruses. Further development of this technology could also lower production costs for many plant species. Perhaps therapies other than heat and chemicals (such as the use of irradiation) will be developed to rid plants of pathogens. Irradiation holds great promise and is being tested on human blood to inactivate viruses such as those that cause hepatitis and AIDS (D. Shoup, personnal communication).

\section{CONCLUSIONS}

Much of vegetative plant propagation was revolutionized in the last century. Plant pathologists have helped propagators by developing and testing methods to rid soil, growing media, tools, containers, 
benches, etc. of pathogens. This has added greatly to the profitability of vegetative plant propagation. Although still an important concern, losses from diseases during propagation are much less today than a century ago. Not only have plant pathologists helped propagators, but the reverse is true as well. By using the vegetative plant propagation techniques of rooting shoot tip cuttings, grafting, and micropropagation using apical meristematic tissues to escape pathogens, researchers have revolutionized an important part of plant pathology.

Much of the new technology applicable directly to plant propagators was included in textbooks and USDA and other governmental bulletins very shortly after being developed or discovered. An example of rapid technology transfer was the commercial production of auxins only about four years after the first tests showed their amazing effect of root initiation. It is a great testament to publishing research results and technology transfer that these new methods were adopted so rapidly by the industry.

Not all inventions were by scientists. The early development of mist propagation and invention of intermittent mist by the Wisconsin nurseryman, Edward J. Gardner, indicates grower innovation. Growers also have taken systems that were developed by scientists and have fine tuned them so that they work well under their commercial conditions. Early use of mist systems and the number of papers on this subject by growers during the first few meetings of the Plant Propagators' Society attest to this.

One of the greatest breakthroughs during the next century will be understanding specifically what makes a cell dedifferentiate to a root or shoot meristematic cell. We will learn the answers to important questions, including gene activation or repression during the initiation of adventitious roots, shoots, and somatic embryos. We will learn what makes a cell receptive to the auxin or cytokinin signal and how can we preprogram our cuttings so that more of their cells will be competent to root. We will learn how we can increase the rooting efficiency of difficult-to-root species, or propagation efficiency of difficult to micropropagate species and clones. Perhaps we will develop techniques so that will allow all temperate woody species to be rooted efficiently during the dormant season when labor is available. We will make plant propagation more efficient, less costly, and more automated and will learn to control pathogens and other problems better than today.

Methods of vegetative propagation will continue to evolve and become more efficient. Expect to see many new innovations as we learn more about plants and their biology.

\section{Literature Cited.}

Adriance, G.W. and F.R. Brison. 1939. Propagation of horticultural plants. McGraw Hill, New York.

Adriance, G.W. and F.R. Brison. 1955. Propagation of horticultural plants. 2nd ed. McGraw Hill, New York.

Agrios, G.N. 1997. Plant pathology. 4th ed., Academic Press, San Diego.

Anderson, W.C. 1984. A revised tissue culture medium for shoot multiplication of rhododendron, J. Amer. Soc. Hort. Sci. 109:343-347.

Anonymous. 1902. Sterilization of soil in greenhouses for fungous diseases. 14th Annu. Rpt., Hatch Expt. Sta., Mass. Agr. College, Public Doc. 33:74-85.

Anonymous. 1903. Experiments in heating soils. 15th Annu. Rpt., Hatch Expt. Sta., Mass. Agr. College, Public Doc. 33:38-42.

Anonymous. 1904. Sterilizing greenhouse soils. U.S. Dept. Agr., Farmers' Bul. 186. (complied from Mass. Sta. Rpts. 1902, p. 74; 1903, p. 38).

Bailey, L.H. 1891. The Nursery-book: A complete guide to the multiplication and pollination of plants. Rural Publ. Co., New York.

Bailey, L.H. 1896. The Nursery-book: A complete guide to the multiplication and pollination of plants. 4th ed. Macmillan, New York.

Bailey, L.H. 1920. The Nursery-manual: A complete guide to the multiplication and pollination of plants. 22nd ed. MacMillan, New York.

Bailey, V.K. 1954. Controlled humidity in greenhouses. Proc. Plant Prop. Soc. 4:121-128.

Baker, K.F. (ed.). 1957. The U.C. system for producing healthy container-grown plants. Univ. Calif. College Agr., Berkeley.

Baker, R. and D.J. Phillips. 1962. Obtaining pathogen-free stock by shoot tip culture. Phytopathology 52:1242-1244.

Barnett, O.W., P.B. Gibson, and A. Seo. 1975. A comparison of heat treatment, cold treatment, and meristem tip-culture for obtaining virus-free plants of Trifolium repens. Plant Dis. Rpt. 59:834-837.

Beinhart, E.G. 1918. Steam sterilization of seed beds for tobacco and other crops. U.S. Dept. Agr. Farmers' Bul. 996.
Bouman, H. and G.-J. de Klerk. 1997. Somaclonal variation, p. 165-183. In: R.L. Geneve, J.E. Preece, and S.A. Merkle (eds.). Biotechnology of ornamental plants. CAB Intl., Wallingford, U.K.

Bouillenne, R. 1933. Neoformation de racines sur hypocotyles chez les plantules de Impatiens balsamina. Ann. Jard. Bot. Buitenzorg 43:29-110

Brown, B.S. 1916. Modern propagation of tree fruits. John Wiley \& Sons, New York.

Chadwick. L.C. 1951. Controlled humidification as an aid to vegetative propagation. Proc. Plant Prop. Soc. 1:38-39.

Chadwick, L.C. and D.C. Kipliger. 1938. The effect of synthetic growth substances on the rooting and subsequent growth of ornamental plants. Proc. Amer. Soc. Hort. Sci. 36:809-816.

Clark, M.F. and A.N. Adams. 1977. Characteristics of the microplate method of enzyme-linked immunosorbent assay for the detection of plant viruses.

Cooper, W.C. 1935. Hormones in relation to root formation on stem cuttings,p. 789-794. In: C.A. Shull, C.B. Lipman, B.E. Livingston, C.R. Ball, and F.E. Lloyd (eds.). Plant physiology. vol.10. Science Press Printing Co., Lancaster, $\mathrm{Pa}$.

Corbett, L.C. 1902. The propagation of plants. U.S. Dept. Agr. Farmers' Bul. 157.

Crocker, W., A.E. Hitchcock, and P.W. Zimmerman. 1935. Similarities in the effects of ethylene and the plant auxins. Contrib. Boyce Thompson Inst. 7:231-248.

Del Tredici, P. 1998. Aging, rejuvenation, and propagation in trees. Comb. Proc. Intl. Plant Prop. Soc. 48:637-642.

Dirr, M.A. 1992. Update on root-promoting chemicals and formulations. Comb. Proc. Intl. Plant Prop. Soc. 42:361-365.

Driver, J.A. and A.H. Kuniyuki. 1984. In vitro propagation of paradox walnut rootstock. HortScience 19:507-509.

Evans, H. 1951. Investigations on the propagation of cacao. Trop. Agr. 28: $147-203$.

Fishel, D.W., J.J. Zaczek, and J.E. Preece. 2003. Positional influence on rooting of shoots forced from the main bole in swamp white oak and northern red oak. Can. J. For. Res. 33:705-711.

Fisher, G.M. 1941. Difficult cuttings respond to use of overhead mist spray. Florist Rev. 88:13-14.

Fisher, G.M. 1943. Conifer propagation under mist. Amer. Nurseryman 77(8): 9-10.

Gardner, E.J. 1941. Propagation under mist. Amer. Nurseryman 73(9):5-7.

Gardner, F.E. 1929. The relationship between tree age and the rooting of cuttings. Proc. Amer. Soc. Hort. Sci. 26:101-104.

Gautheret, R.J. 1939. Sur la possibilite de realiser la culture indefinie des tissus de tubercules de carrotte. C.r. Acad. Sci. (Paris). 208:118-120.

Geneve, R. 2001. Plant propagation techniques: A historical perspective. Comb. Proc. Intl. Plant Prop. Soc. 51:370-375.

Goebel, K. 1900. Organography of plants. part 1. Clarendon Press, Oxford.

Gossard, A.C. 1944. The rooting of pecan softwood cuttings under continuous mist. Proc. Amer. Soc. Hort. Sci. 44:251-254.

Hackett, W.P. and J.R. Murray. 1997. Approaches to understanding maturation or phase change, p. 73-86. In: Geneve, R.L, J.E. Preece, and S.A. Merkle (eds.). Biotechnology of ornamental plants. CAB Intl., Wallingord, U.K.

Hartley, C. and R.G. Pierce. 1917. The control of damping-off of coniferous seedlings. U.S. Dept. Agr. Bul. 453.

Hartmann, H.T. and D.E. Kester. 1959. Plant propagation principles and practices. Prentice-Hall, Englewood Cliffs, N.J.

Hartmann, H.T. and D.E. Kester. 1968. Plant propagation principles and practices. 2nd ed. Prentice-Hall, Englewood Cliffs, N.J.

Hartmann, H.T. and D.E. Kester. 1975. Plant propagation principles and practices. 3rd ed. Prentice-Hall, Englewood Cliffs, N.J.

Hartmann,H.T. and D.E. Kester. 1983. Plant propagation principles and practices. 4th ed. Prentice-Hall, Englewood Cliffs, N.J.

Hartmann, H.T., D.E. Kester, and F.T. Davies, Jr. 1990. Plant propagation principles and practices. 5th ed. Prentice-Hall, Englewood Cliffs, N.J.

Hartmann, H.T., D.E. Kester, F.T. Davies, Jr., and R.L. Geneve. 1997. Plant propagation principles and practices. 6th ed. Prentice-Hall, Upper Saddle River, N.J.

Hartmann, H.T., D.E. Kester, F.T. Davies, Jr., and R.L. Geneve. 2002. Hartmann and Kester's plant propagation principles and practices. 7th ed. PrenticeHall, Upper Saddle River, N.J.

Henry, P.H. and J.E. Preece. 1997a. Production and rooting of shoots generated from dormant stem sections of Acer species. HortScience 32:1274-1275.

Henry, P.H. and J.E. Preece. 1997b. Production of shoots from dormant Acer as influenced by length and caliper of stem sections. J. Environ. Hort. 15: $153-156$.

Hershey, D.R. 1996. Doctor Ward's accidental terrarium. Amer. Biol. Teacher 58:276-281

Hess, C.E. 1954. Factors influencing propagation under mist. Proc. Plant Prop. Soc. 4:104-109. 
Hess, C.E. and W.E. Snyder. 1953. A simple and inexpensive time clock for regulating mist in plant propagation procedures. Proc. 3rd Annu. Mtg. Plant Prop. Soc. p 56-60.

Hitchcock, A.E. 1935a. Indole-3- $n$-propionic acid as a growth hormone and the quantitative measurement of plant response. Contrib. Boyce Thompson Inst. 7:87-95.

Hitchcock, A.E. 1935b. Tobacco as a test plant for comparing the effectiveness of preparations containing growth substances. Contrib. Boyce Thompson Inst. 7:349-364.

Hitchcock, A.E. and P.W. Zimmerman. 1936. Effect of growth substances on the rooting response of cuttings. Contrib. Boyce Thompson Inst. 8:63-79.

Holmes, F.O. 1948. Elimination of spotted wilt from a stock of dahlia. Phytopathology 38:314 (abstr.).

Holmes, F.O. 1955. Elimination of spotted wilt from dahlias by propagation of tip cuttings. Phytopathology 45:224-226.

Holmes, F.O. 1956. Elimination of aspermy virus from the nightingale chrysanthemum. Phytopathology 46:599-600.

Hottes, A.C. 1918. Commercial plant propagation: An exposition of the art and science of increasing plants as practiced by the nurseryman, florist, and gardener. A.T. De La Mare Co., New York.

Hottes, A.C. 1922. Practical plant propagation: An exposition of the art and science of increasing plants as practiced by the nurseryman, florist, and gardener. 2nd ed. A.T. De La Mare Co., New York.

Hottes, A.C. 1934. Plant propagation: 999 questions answered. A.T. De La Mare Co., New York.

Hottes, A.C. 1949. How to increase plants. A.T. De La Mare Co., New York.

Huetteman, C.A. and J.E. Preece. 1993. Thidiazuron: A potent cytokinin for woody plant tissue culture. Plant Cell Tiss. Org. Cult. 33:105-119.

Jablonski, J.R. and F. Skoog. 1954. Cell enlargement and cell division in excised tobacco pith tissue. Physiol. Plant. 7:16-24.

Kains, M.G. 1916. Plant propagation: Greenhouse and nursery practice. Orange Judd Publ. Co., New York.

Kains, M.G. and L.M. McQuesten. 1938. Propagation of plants: a complete guide for professional and amateur growers of plants by seeds, layers, grafting, and budding, with chapters on nursery and greenhouse management. Orange Judd Publ. Co., New York.

Kassanis, B. 1957. The use of tissue cultures to produce virus-free clones from infected potato varieties. Ann. Appl. Biol. 45:422-427.

Kiplinger, D.C. 1946. Humidity in the greenhouse. Monthly Bul. Ohio Florists Assn. 196:2-8.

Kögl, F. 1933. On plant hormones (auxin A and auxin B). Rep. British Assn. p. 600-609.

Kögl, F., A.J. Haagen-Smit, and H. Erxleben. 1934a. Über die neues auxin (heteroauxin) aus hain. XI Mitteilung. Zeitschr. Physiol. Chem. 228:90-103.

Kögl, F. And D.G.F.R. Kostermans. 1934b Hetero-auxin als stoffweckselprodukt niederer pflanzlicher organismen. Isolierung aus hefe. XIII Mitteilung. ber die neues auxin (heteroauxin) aus hain. XI Mitteilung. Zeitschr. Physiol Chem. 228:113-121.

Knudson, L. 1922. Nonsymbiotic germination of orchid seeds. Bot. Gaz. 73: $1-25$.

Larkin, P.J. and W.R. Scowcroft. 1981. Somaclonal variation-A novel source of variability from cell cultures for plant improvement. Theor. Appl. Genet. 60:197-212.

Laurie, A. and L.C. Chadwick. 1931. The modern nursery. A guide to plant propagation, culture, and handling. Macmillan, New York.

Laurie, A. and J.B. Fueglein. 1939. Biological activity in steam sterilized soils in the greenhouse. Proc. Amer. Soc. Hort. Sci. 36:837-840.

Loeb, J. 1917a. The chemical basis of axial polarity in regeneration. Science 46:547-551.

Loeb, J. 1917b. Influence of the leaf upon root formation and geotropic curvature in the stem of Bryophyllum calycinum and the possibility of a hormone theory of these processes. Bot. Gaz. 63:25-50.

Lloyd, G. and B. McCown. 1980. Commercially-feasible micropropagation of mountain laurel, Kalmia latifolia, by use of shoot-tip culture. Comb. Proc. Intl. Plant Prop. Soc. 30:421-427.

Macdonald, B. 1986. Practical woody plant propagation for nursery growers, vol. 1. Timber Press, Portland, Ore.

Mahlstede, J.P. and E.S. Haber. 1957. Plant propagation. John Wiley and Sons, New York.

Marcotrigiano, M. 1997. Chimeras and variegation: patterns of deceit. HortScience 32:773-784.

McGranahan, G.H., J.A. Driver, and W. Tulecke. 1987. Tissue culture of Juglans, p. 261-271. In: J.M. Bonga and D.J. Durzan (eds.). Cell and tissue culture in forestry. vol. 3. Case histories: Gymnosperms, angiosperms and palms. Martinus Nijhoff, Dordrecht.

Mendel, K. 1992. The history of plant propagation methods during the last 70 years. Acta Hort. 314:19-26.

Milbocker, D.C. 1977. Propagation in a humid chamber. Comb. Proc. Intl. Plant
Prop. Soc. 27:455-461.

Milbocker, D.C. 1983. Ventilated high humidity propagation. Comb. Proc. Intl. Plant Prop. Soc. 33:384-387.

Milbocker, D.C. and R. Wilson. 1979. Temperature control during high humidity propagation. J. Amer. Soc. Hort. Sci. 104:123-126.

Miller, C. and F. Skoog. 1953. Chemical control of bud formation in tobacco stem segments. Amer. J. Bot. 40:768-773.

Miller, C.O., F. Skoog, F.S.Okumura, M.H. Von Saltza, and F.M. Strong. 1956. Isolation, structure and synthesis of kinetin, a substance promoting cell division. J. Amer. Chem. Soc. 78:1375-1380.

Miller, C.O.,F. Skoog, F.S.Okumura, M.H. Von Saltza, and F.M. Strong. 1955a. Structure and synthesis of kinetin. J. Amer. Chem. Soc. 77:2662-2663.

Miller, C.O., F. Skoog, M.H. Von Saltza, and F.M. Strong. 1955b. Kinetin, a cell division factor from deoxyribonucleic acid. J. Amer. Chem. Soc. 77:1392.

Morel, G. and C. Martin. 1952. Guerison de dahlias atteints d'une maladie a virus. C.R. Acad. Sci. Paris. 235:1324-1325.

Morel, G. and C. Martin. 1955. Guerison de pommes de terre atteintes de maladies a virus. Comptes Rendus de l'Acadamie d'agriculture de France 41:472-475

Mullin, R.H., S.H. Smith, N.W. Frazier, D.E. Schlegel, and S.R. McCall. 1974. Meristem culture frees strawberries of mild yellow edge, pallidosis, and mottle diseases. Phytopathology 64:1425-1429.

Murashige, T. 1974. Plant propagation through tissue culture. Annu. Rev. Plant Physiol. 25:135-166.

Murashige, T. and F. Skoog. 1962. A revised medium for rapid growth and bioassays with tobacco tissue culture. Physiol. Plant. 15:473-497.

Naylor, J., G. Sander, and F. Skoog. 1954. Mitosis and cell enlargement without cell division in excised tobacco pith tissue. Physiol. Plant. 7:25-29.

Nobelcourt, P. 1939. Sur la perennite et l'augmentation de volume des cultures de tissus vegetaux. C.r. Soc. Biol. (Paris). 130:1270.

Olsen, C.M. 1964. Aerated steam treatment of soil-Its principles and application. Comb. Proc. Intl. Plant Prop. Soc. 14:305-308.

O'Rourke, F.L. 1949. Mist humidification and the rooting of cuttings (progress report). Mich. Agr. Expt. Sta. Quart. Bul. 32:245-249.

O'Rourke, F.L. and J.E. Moulton. 1947. The use of new type atomizers in the propagation greenhouse. Mich. Agr. Expt. Sta. Quart. Bul. 30:92-95.

Preece, J.E. 1993. Basics of propagation by cuttings-Temperature. Comb. Proc. Intl. Plant Prop. Soc. 43:441-444.

Preece. 1997. Axillary shoot proliferation, p. 35-43. In: R.L. Geneve, J.E. Preece, and S.A. Merkle (eds.). Biotechnology of ornamental plants. CAB Intl., Wallingford, U.K.

Preece, J.E. 2001. The most tricky part of micropropagation: establishing plants in greenhouses and fields. Comb. Proc. Intl. Plant Prop. Soc. 51:300-303.

Preece, J.E., D.I. Ledbetter, and J.J. Zaczek. 2001. Rooting softwood cuttings collected from forced large stems of oakleaf hydrangea and american chestnut. Comb. Proc. Intl. Plant Prop. Soc. 51:267-270.

Preece, J.E. and E.G. Sutter. 1991. Acclimatization of micropropagated plants to the greenhouse and field, p. 71-93. In: Debergh, P. and R.H. Zimmerman (eds.). Micropropagation. Kluwer, Dordrecht, The Netherlands.

Preece, J.E., J.W. Van Sambeek, P.H. Henry, and J. Zaczek. 2002. Forcing the tissue. Amer. Nurseryman 196(7):26-30, 32, 34.

Press, T.F. 1983. Propagation: fog not mist. Comb. Proc. Intl. Plant Prop. Soc. 33:100-109.

Quak, F. 1957. Meristeemcultuur, gecombineerd met warmtebehandeling voor het verkrijgen van virusvrije anjers. Tidsskr. Pl.-ziekten 63:13-14.

Raines, M.A. 1940. Some uses of a spray chamber in experimentation with plants. Amer. J. Bot. 27:18s (abstr.)

Raines, M.A. 1941. Methods of growing plants in water and air. Torreya 41: 103-104 (abstr.)

Reinert, J. 1958. Morphogenese und ihre kontrolle an gewebekulturen aus carotten. Naturwissenschaften 45:344-345

Sachs, J. 1879. Stoff und form der pflanzenorgane. I. Arb. Bot. Inst. Würtzburg 2:452-488.

Saha, S., S. Kester, E. Wilkerson, J. Buxton, and R. Geneve. 2001. Design of a propagation unit that independently controls atmospheric and medium moisture. Comb. Proc. Intl. Plant Prop. Soc. 51:518-520.

Scowcroft, W.R. and P.J.Larkin. 1982. Plant biotechnology, somaclonal variation, and varietal improvement. Comb. Proc. Intl. Plant Prop. Soc. 82:80-89.

Sheridan, W.F. 1974. Plant regeneration and chromosome stability in tissue culture, p.263-295. In: L. Ledoux (ed.). Genetic manipulation with plant material. Plenum and Co., London.

Skinner, H.T. 1937. Rooting response of azaleas and other Ericaceous plants to auxin treatments. Proc. Amer. Soc. Hort. Sci. 35:830-838.

Skirvin, R.M. 1978. Natural and induced variation in tissue culture. Euphytica 27:241-266.

Snyder, W.E. 1954. Possibilities with mist propagation. Proc. Plant Prop. Soc. 4:89-103.

Steward, F.C. 1958. Growth and organized development of cultured cells. II. 
Organization in cultures grown form freely suspended cells. Amer. J. Bot. 45:653-704.

Stoutemyer, V.T. 1942. Humidification and the rooting of greenwood cuttings of difficult plants. Proc. Amer. Soc. Hort. Sci. 40:301-325.

Strong, F.M. 1958. Topics in microbial chemistry. Antimycin, coenzymeA, kinetin and kinins. Wiley, New York.

Templeton, H.M. 1953. The phytotektor method of rooting cuttings. Proc. 3rd Annu. Mtg. Plant Prop. Soc. p. 51-52.

Templeton, H.M. 1955. The electronic leaf. Proc. Plant Prop. Soc. 5: 131-133.

Thimann, K.V. and F.W. Went. 1934. On the chemical nature of the rootforming hormone. Proc. K. Ned. Akad. Wet. 37:456-459.

Thimann, K.V. and J.B. Koepfli. 1935. Identity of the growth-promoting and root-forming substances of plants. Nature(London)(Suppl.)135:101-102.

Thompson, A.D. 1956. Heat treatment and tissue culutre as a means of freeing potatoes from virus Y. Nature 177:709.

Tilney-Bassett, R.A.E. 1986. Plant chimeras. Edward Arnold, London.

Van Sambeek, J.W., L.J. Lambus, S.B. Khan, and J.E. Preece. 1997a. In vitro establishment of tissues from adult black walnut. In: J.W. Van Sambeek (ed.). Knowledge for the future of black walnut. Proc. 5th Black Walnut Symp. 1996, Springfield, Mo. Gen. Tech. Rpt. NC-191. St Paul, Minn., USDA For. Serv.

Van Sambeek, J.W., L.J. Lambus, and J.E. Preece. 1997b. Production of epicormic sprouts on branch segments of adult black walnut for in vitro culture. Annu. Rpt. N. Nut Growers Assn. 88:93-104.

Van Sambeek, J.W. and J.E. Preece. 1999. Forcing environment affects epicormic sprout production from branch segments for vegetative propagation of adul hardwoods. Comb. Proc. Intl. Plant Prop. Soc. 49:156-158.

Vieitez, A.M., M.C. Sanchez, J.B. Amo-Marco, and A. Ballester. 1994. Forced flushing of branch segments as a method for obtaining reactive explants of mature Quercus robur trees for micropropagation. Plant Cell Tiss. Organ Cult. 37:287-295.

Voller, A., A. Bartlett, D.E. Bidwill, M.F. Clark, and A.N. Adams. 1976. The detection of viruses by enzyme-linked immunosorbent assay (ELISA). J. Gen. Virol. 33:165-167.

Ward. W.F. 1954. Mist propagation in open frames. Proc. Plant Prop. Soc. 4 109-113.

Wells, J.S. 1953. Outdoor propagation under constant mist. Amer. Nurseryman. 97(11): 14, 51-58.

Wells, J.S. 1955. Plant propagation practices. Macmillan, New York.

Went, F.W. 1929. On a substance causing root formation. Proc. K. Ned. Akad. Wet. 32:35-39.

Went, F.W. 1934. A test method for rhizocaline, the rootforming substance. Proc. K. Ned. Akad. Wet. 37:445-455.

White, P.R. 1934. Potentially unlimited growth of exicised tomato root tips in a liquid medium. Plant Physiol. 9:585-600.

Wright, R.C.M. 1955. Plant propagation: A practical guide to the various methods of propagating trees and shrubs, herbaceous plants, fruits, and vegetables. Ward, Lock \& Co. Ltd., London.

Zimmerman, P.W. and F. Wilcoxon. 1935. Several chemical growth substances which cause initiation of roots and other responses in plants. Contrib. Boyce Thompson Inst. 7:209-229.

Zimmerman, R.H. and R.J. Griesbach. 2001. Status of the commercial micropropagation industry. Comb. Proc. Intl. Plant Prop. Soc. 51:479-481. 